\title{
33. LITHOLOGIC SUMMARY, LEG 25, DEEP SEA DRILLING PROJECT ${ }^{1}$
}

\author{
W. A. Girdley, Mesa College, Grand Junction, Colorado \\ Lucien Leclaire, Laboratoire de Geologie du Museum National d'Histoire Naturelle, Paris \\ Casey Moore, University of California, Santa Cruz, Santa Cruz, California \\ T. L. Vallier, Scripps Institution of Oceanography, La Jolla, California \\ and \\ Stan M. White, California State University, Fresno, California
}

\section{INTRODUCTION}

Sedimentary deposits recovered from the western and southwestern Indian Ocean during Leg 25 of the Deep Sea Drilling Project range in composition from biogenous ooze and brown clay to terrigenous and volcanogenic sediments. The sediments were recovered from cores of 13 holes that were drilled at 11 sites (Figure 1), and igneous rocks were obtained from five holes.

This lithologic summary is designed to recapitulate data from chapters in the volume and to discuss some aspects which either were not brought out in the chapters or were only casually mentioned. The information contained in this chapter is essentially of two types. The first is summary data for individual sites including time-stratigraphic diagrams. The second type is in the form of discussions on specialized topics that are related to the deposits of the western and southwestern Indian Ocean.

For the site summaries, it is our intent to present a time-stratigraphic analysis of the sequence at each site. The vehicle to accomplish this is a series of time-rock graphic illustrations (Figures 2 through 9) which show time in millions of years as the vertical axis and a lithologic graphic log, time-rock units present, lithologic descriptions, and comments as the horizontal axis. The Cenozoic time scale used is that of Berggren (1972) and the Cretaceous scale is that of Casey (1964). The lithologic column at each site is plotted as a function of time rather than of thickness.

In the construction of each time-rock column, several assumptions have been made which warrant further discussion. Sediment types shown in the graphic logs have been broadly grouped (using appropriate symbols) into pelagic biogenic ooze, pelagic brown clay, volcanogenic, and terrigenous so as to best reflect the mode of origin. Percentage estimations in the graphic logs were made from results presented in other chapters of this volume (site report chapters and those by Leclaire, Moore, Girdley and White, Vallier, and Kent.) Other significant sediment features, such as volcanic contributions, glauconite, etc., are noted by appropriate symbols, but there is no attempt to show the actual percentage of these components. The term basement used in the discussions implies only the acoustic basement. Finally, no distinction is made on the graphic logs between cored and noncored intervals. The reader

\footnotetext{
${ }^{1}$ With a contribution on sedimentation rates by Barbara Zobel, Bundesanstalt für Bodenforschung, Hannover, Germany.
}

should consult the appropriate site report chapter for this information.

Figures 2 through 9 also provide the following: (1) those parts of the time-rock units that are actually present at each site; (2) a general description of the lithology representing the geologic time interval; and (3) succinct interpretations and comments concerning the sediments and their characteristics at each site.

Preceding the above time-stratigraphic site summaries, a brief introductory discussion of each site is provided. These discussions present significant assumptions and/or points deemed necessary for the reading and interpretation of the figures. The topical discussions which follow the site summaries section present additional, significant features of the Leg 25 sediments, the details of which are omitted under "comments" on the graphic summary sheets.

\section{SITE LITHOLOGIC SUMMARIES}

\section{Site 239}

Most of the time-stratigraphic graphic summary (Figure 2) for Site 239 is straightforward. A notable point, however, is that neither the upper Oligocene-lower Miocene nor the lower-middle Miocene boundaries were recognized in the recovered sediments. Some missing intervals (i.e., lower and middle Oligocene) may be represented in noncored intervals.

\section{Site 240}

This site has two holes, 240 and $240 \mathrm{~A}$, each with different coring depths and coring intervals (Figure 3 ). This fact, plus the occurrence of a different subbottom structure at the two holes, means that neither lithologic unit nor paleontologic boundaries precisely coincide for the two holes. In Hole 240, the lower Miocene contains a mixed fossil assemblage which overlies a lower Eocene reworked assemblage; in Hole 240A, a mixed Miocene assemblage overlies a lower Eocene or upper Paleocene assemblage. Also, in Hole 240 a Quaternary-Pliocene boundary was established.

\section{Site 241}

The presentation for Site 241 (Figure 4) shows three poorly defined boundaries. These are the lower Senonian (or Turonian) to Campanian, the lower Eocene to Paleocene, and the lower-upper Pliocene boundary. 


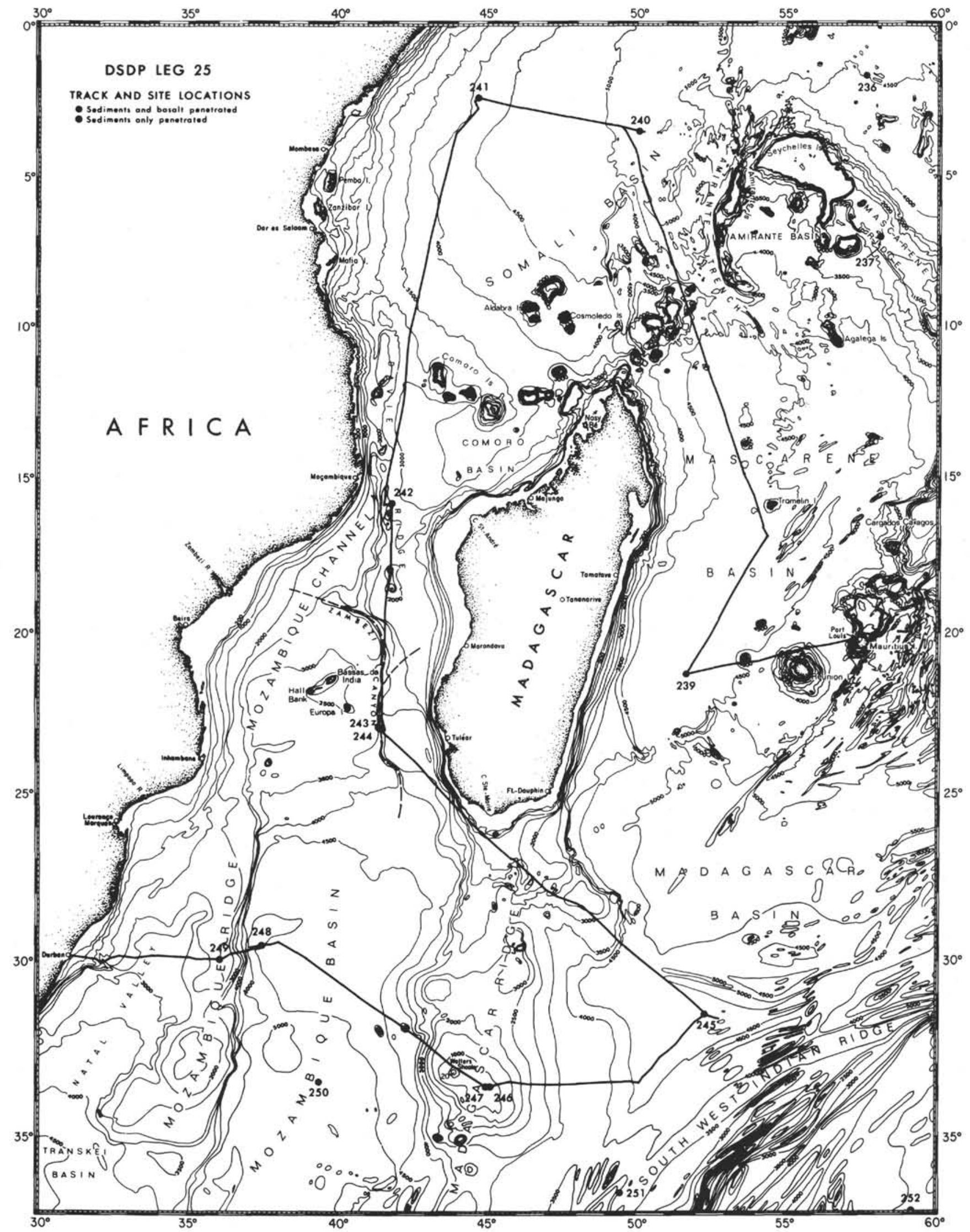

Figure 1. Site locations and track of Leg 25 in the southwestern Indian Ocean. 


\section{Site 242}

The lower and upper Pliocene boundary was not distinguished in the cores (Figure 5). The middle Oligocene was not noted in the cores, although both lower and upper Oligocene occur.

\section{Site 245}

A few interpretations regarding paleontologic boundaries warrant further explanation here (also see Chapter 5, this volume). The uppermost cored section consists of a middle Miocene reworked fauna overlying an upper Eocene deposit (Figure 6). The lack of paleontologic control in the brown clay prevents a clear-cut time breakdown and also prevents establishing any post-Miocene time-rock units. The "basement" here is a diabase sill that was dated $(\mathrm{K} / \mathrm{Ar})$ at $27 \pm 3$ m.y. (McKee, this volume), and the oldest sediment cored above the basalt is lower Paleocene. There were two holes at this site and the graphic column is a summation.

\section{Site 246}

At this site, the Miocene-Oligocene boundary may be present, but it is not definitely established. Only small amounts of middle Eocene and Oligocene sediments were recovered (Figure 7). The middle Miocene is recognized in the sediments; however, the presence of lower Miocene is inferred and is believed to occur in a noncored interval. The lower Pliocene overlies the middle Miocene section.

\section{Site 248}

The basalt cored at this site has a $\mathrm{K} / \mathrm{Ar}$ date of $72 \pm 7$ m.y. (McKee, this volume). The actual basalt-sediment contact was not recovered, and the age of the oldest sediment above the basalt is lowermost Eocene (Figure 8). A few meters of sediment directly above the basalt was not recovered and may be of Paleocene age. Although the lower Miocene was not recognized in the cores, it may be present in a noncored interval.

\section{Site 249}

The time scale used as the vertical axis for Figure 9 has been adjusted to allow the diagram to be in agreement with the scales of Figures 2-8. Thus two gaps (artificial) were placed in the time scale.

\section{DISCUSSIONS ON SPECIALIZED TOPICS}

\section{Massive Sands in the Abyssal Plain Environment}

The massive sands cored from the abyssal plains of the Somali (Site 240) and Mozambique (Site 248) basins are of exceptional topical and regional interest. The main topical problem regarding these sands is to determine how this coarse homogeneous material was transported long distances (at least $750 \mathrm{~km}$ ) over slopes as gentle as 1:1000. An empirical textural comparison of the massive sands with deposits of turbidity currents and of traction currents suggests that the massive sands were moved by a mechanism transitional between suspension and bed load transport (Moore, this volume). High energy turbidity currents undoubtedly drag some coarse sediment along their lower contact as a "bed load," and, therefore, may account for the massive sands. However, the presence of these high energy flows on the abyssal plain, far removed from the base of slope region, requires that they have great momentum and minimal frictional resistance.

A large volume (mass) of material would increase the momentum of a given flow; whereas, distribution along a well-defined channel would lower frictional resistance. Both of the above factors are qualitatively necessary to move the massive sand deposits to the abyssal plain and are permitted within the regional framework (see below).

Regional correlations indicate contemporaneous accumulation of massive sand in the Somali and Mozambique basins (Figure 10). Although it is not possible to establish the exact source area for the massive sand, detailed mineralogy clearly indicates derivation from the crystalline basement of Africa and Madagascar (Girdley and White, this volume). Miocene (Sites 240 and 248) and Eocene (Site 240) massive sand occurrences show a reasonable correlation with accelerated sedimentation rates along the East African shelf (Kent et al., 1971) (Figure 10). According to Kent et al. (1971), this acceleration in sedimentation rates was related to faulting and/or uplift of the African craton; these tectonic events, in turn, are recorded by the massive sand deposits. The large volume of sediment on the continental shelf, occurring as a result of high sedimentation rates, would provide the necessary material to generate large density current flows.

Adjacent drill sites provide information on facies variation of the massive sands. In the Somali Basin, continental rise sediments (Site 241) of the same age as the massive sands consist of graded beds interlayered with hemipelagic deposits. These graded beds show mineralogy similar to the massive sands (Girdley and White, this volume) and apparently represent overbank deposits from channelized density flows which bypassed this environment. Site 250 (Leg 26) is located downslope from Site 248 in the Mozambique Basin. At Site 250, a thick sequence of terrigenous clays (Luyendyk, Davies, et al., 1973) is time equivalent to the Miocene massive sands. These clays show no evidence of turbidity current action and apparently were deposited by bottom currents from the vicinity of Site 248 (T. Davies, personal communication). Thus, facies data from both the Somali and Mozambique basins suggest minimal lateral extent of the massive sands and are consistent with their distribution in well-defined submarine channels.

The Miocene massive sand of the Mozambique Basin may record the initiation of transport of coarse material down the Zambezi Submarine Canyon. This movement of coarse detritus continues today (see Chapter 6, this volume).

\section{Cretaceous Sediments at Site 249}

Cretaceous sediments in Mozambique and in Site 249 are partly correlative and were deposited in similar environments. Because of this correlation of onshore and offshore stratigraphy and the lithologic similarities, a short discussion regarding the geologic development of the area seems worthwhile.

Flores (1973) and Blant (1973) discuss the Cretaceous rocks in South Africa, Mozambique, and Madagascar, and Flores (1970) relates not only volcanism but also 


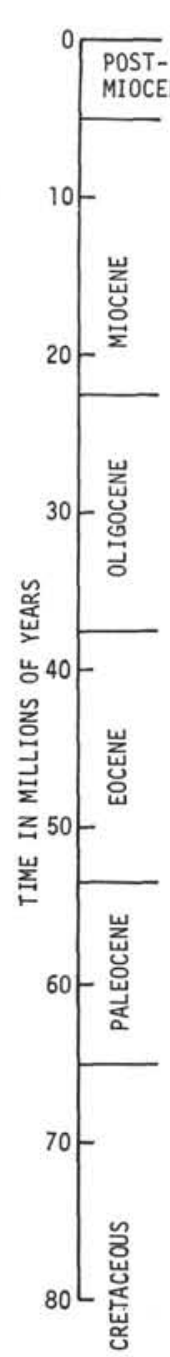

GRAPHIC LOG

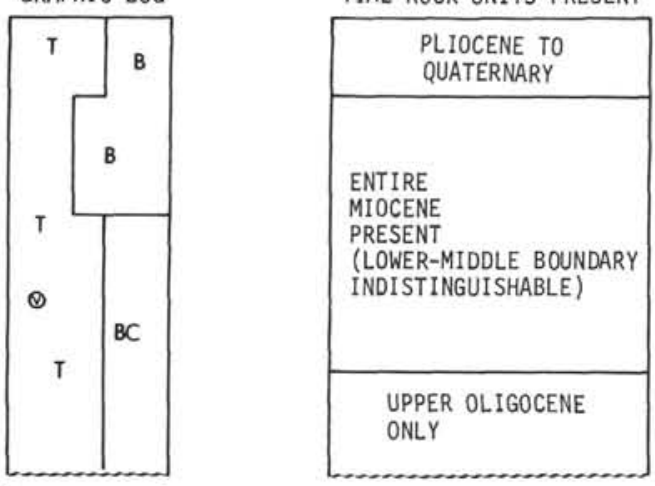

UPPERMOST EOCENE HIATUS(?) |
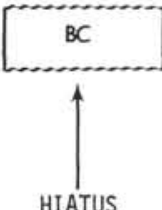

HIATUS

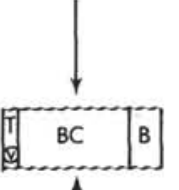

$\uparrow$ HIATUS
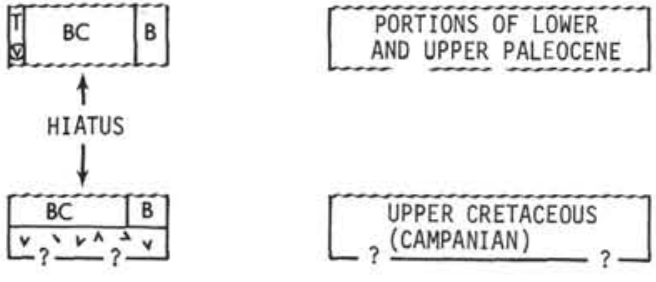
(CAMPANIAN)

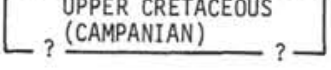

LEGEND (For Figures 2-9).
LITHOLOGIES Green and gray SILTY CLAY, SILT-
BEARING NANNO OOZE CLAYEY SILT, CLAYEY SILT SAND

Gray CLAY-RICH NANNO OOZE

Green and gray SILTY CLAY, CLAY/ CARBONATE-RICH NANNO OOZE

BROWN SILTY CLAY, BROWN CLAY

BROWN SILTY CLAY, BROWN CLAY

BROWN SILTY CLAY, BROWN CLAY

The appearance near the top of the sequence of calcareous components which overlie brown clays seems to indicate that the CCD lowered during mid-Miocene. Abundant terrigenous sediment comprising upper 0ligocene through post-Miocene is in agreement with Tertiary erosional history of Madagascar (Kent, this volume). The mineralogy of terrigenous components indicates silicic plutonic and gneissic metamorphic provenances, and heavy minerals identified are known to occur in such rocks on Madagascar (Girdley and beds, are restricted to Quaternary and probably red flect active erosion of Madagascar and a lowered sea level.

Dominance of brown clay from upper Eocene to the bottom of the hole indicates that the sea floor was at or below CCD. The brown clay dated as late Eocene may in fact contain reworked nannofossils and thus may be of younger age.

The hiatuses may correspond to times of peneplanation on Africa (Kent, this volume). Leclaire (this volume) attributes these breaks to current scouring.

The CCD was probably near the sediment-water interface in Late Cretaceous and Paleocene time, based on the presence of calcareous tests which ex

Volcanic contributions, both direct and indirect, are noted for Paleocene and Miocene times (Vallier; Girdley and White, this volume). Paleocene

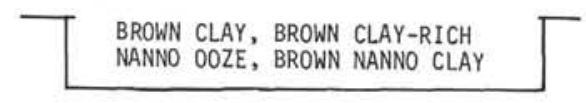
and later Tertiary vol canism in Madagascar and in the Mascarene islands was noted by vallier (this volume). "Basement" is tholeiitic basalt (Erlank and Reid, this volume). NANNO DOZE, BROWN NANNO CLAY

FINE GRAINED FLOW ROCKS

B biogenic pelagic BC brown clay - pelagic

Q volcanic contribution $T$ terrigenous

$\otimes_{2}$ volcanic

- glauconite

(2) chert

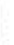

(n)

Figure 2. Site summary diagram for Site 239. 


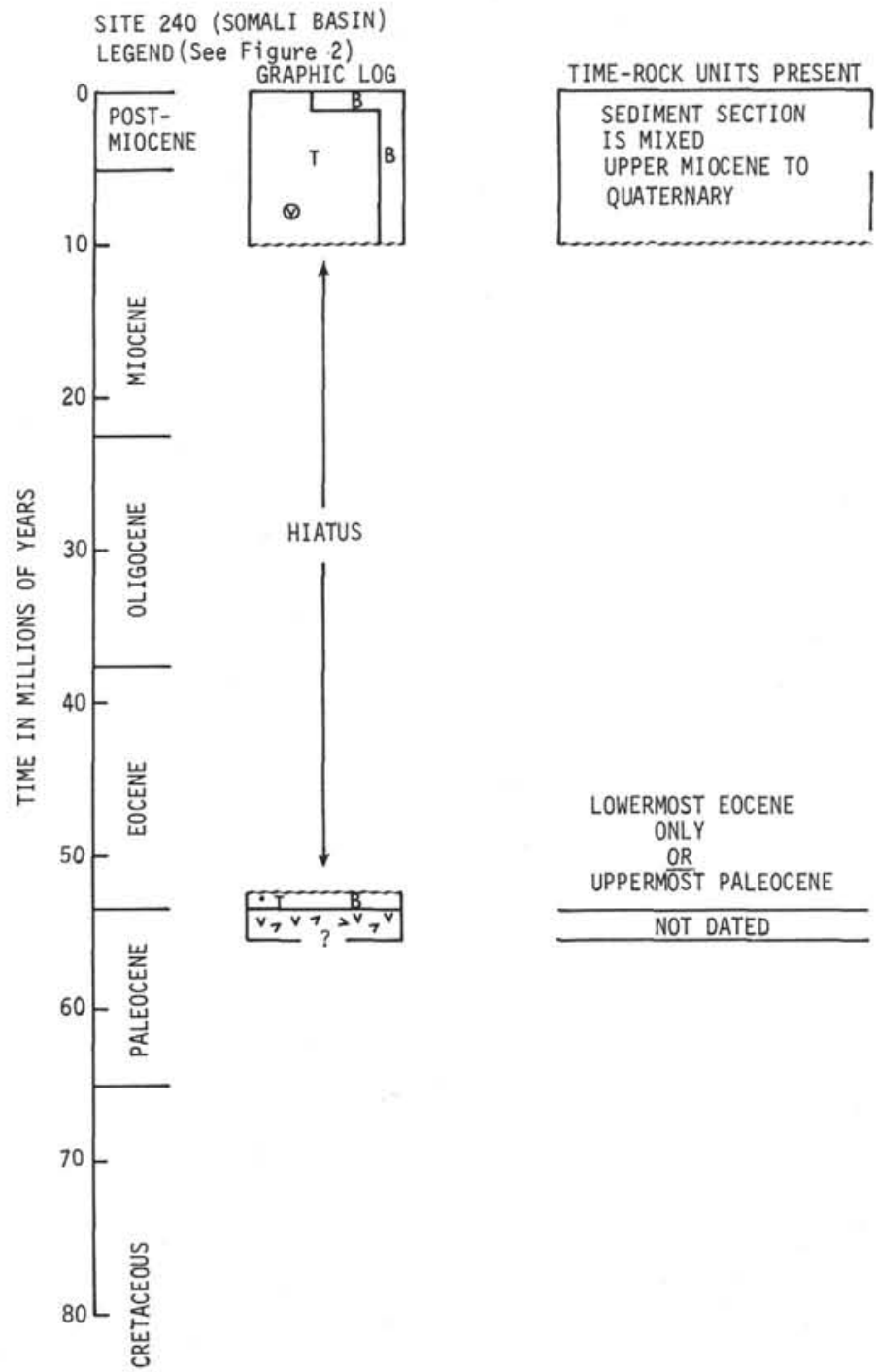

LITHOLOGIES

Green, gray olive SILTY CLAY/NANNORICH RAD OOZE; NANNO BEARING/RICH CLAYEY SILT and SILTY CLAY, MASSIVE SAND

Brown, yellow NANNO OOZE, SILTY CLAY, SANDY SILT, SAND

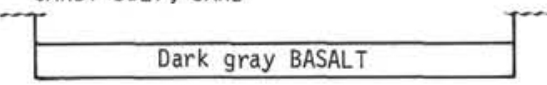

Site 240

Coments

Terrigenous contributions dominate the upper Miocene to Quaternary section, but it is notable that biogenous components increase significantly in the Quaternary. This is surely due to increased productivity as evidenced by simultaneous increases in both calcareous and siliceous tests.

Terrigenous minerals correspond to ones known from silicic provenances of eastern Africa and the Seychelles (Girdley and White, this volume). Massive sands encountered in Eocene and Miocene sediments reflect uplift of adjacent cratonic sources (Moore, this volume). Such sands apparently were deposited by the abyssal plain by submarine channels. Volcanic components are present al though rare; volcanism had a volumetrically minor effect on Site 240 .

There is uncertainty as to the termination of the Eocene to Miocene hiatus. The hiatus may be due to physical removal of the sediment record by currents or to dissolution of calcareous biogenous components (see discussion of hiatuses, this chapter).

Biogenous pelagic sediments at the base of the sediment column appear mixed and displaced; therefore, their origin is highly speculative. Benthonic species indicate an impoverished bathyal environment (Sigal, this volume)

The undated basalt encountered at the bottom of the hole is discussed by Erlank and Reid (this volume).

Figure 3. Site summary diagram for Holes 240 and $240 \mathrm{~A}$. 
SITE 241 (EAST AFRICAN CONTINENTAL RISE)

LEGEND (See Figure 2).

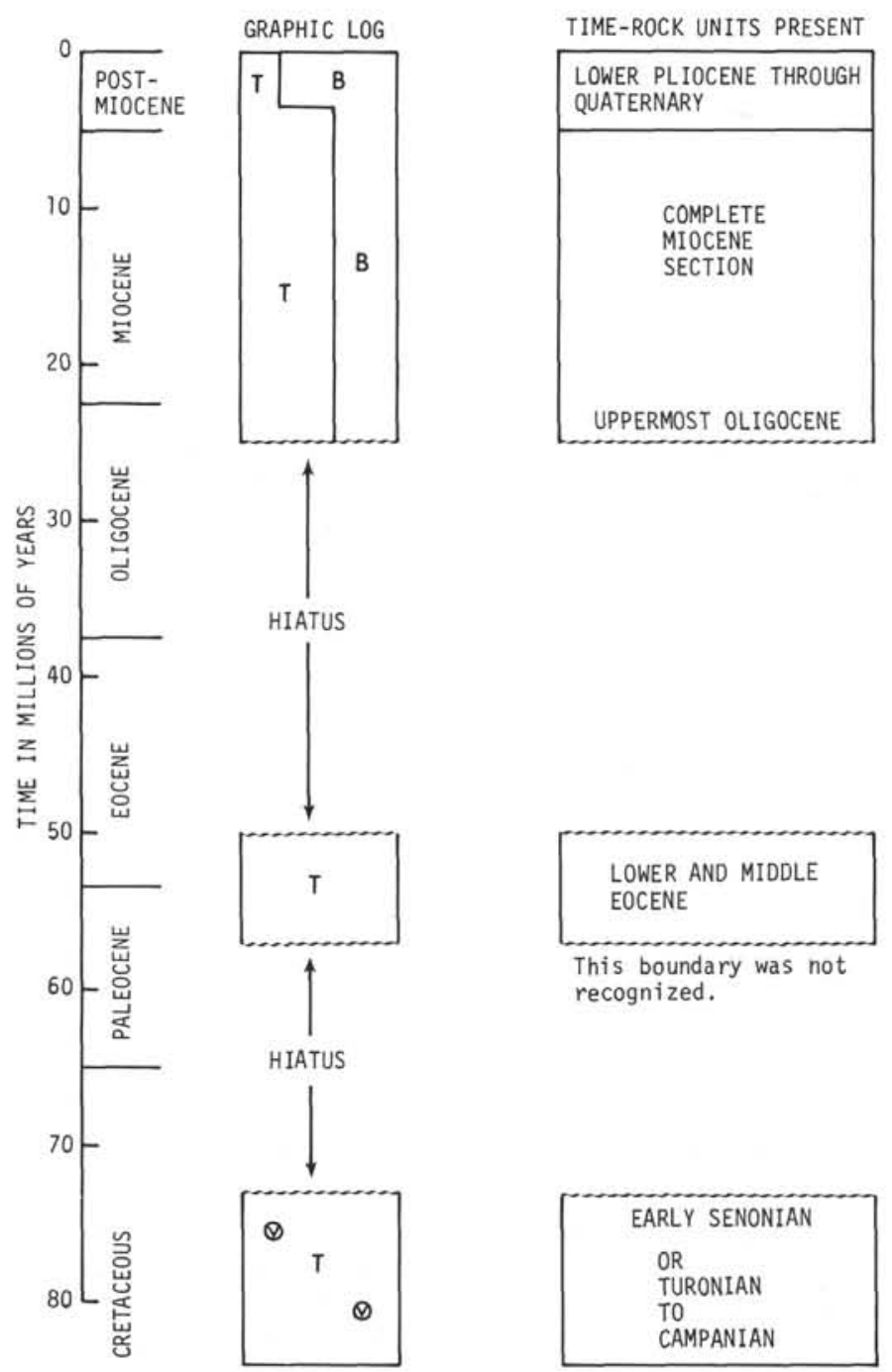

LITHOLOGIES

\begin{tabular}{|l|}
\hline Greenish gray CLAY-RICH NANNO OOZE, \\
CLAYEY NANNO OOZE, NANNO CLAY \\
\hline \\
Greenish gray CLAY, CLAYEY NANNO \\
OOZE, NANNO CLAY, AND SILTY CLAY \\
\end{tabular}
AND CLAY

Dark greenish gray and brown CLAYSTONE (NANNO-RICH SILTY, SILT-RICH)
Site 241

An Eocene-0ligocene hiatus is well marked by a distinct change from almost totally terrigenous sed iments to those abundant in calcareos biogens components. This sharp increase in biogenous sediment, accompanied by increases in organic carbon and pyrite in post-Miocene time, is related to increased productivity. Terrigenous detritus contains minerals, probably derived from silicic plutons and gneisses, and volcanic constituents which may have originated in eastern Africa and/or western Madagascar (Girdley and White, this volume). Both hi atuses may correlate with peneplain development in East Africa (Kent, this volume)

Upper Cretaceous turbidites, deposited below the CCD, indicate deep-water deposition ( $f$ lys $\mathrm{ch}$ ) along cast Africa and preclude location of Madagascar

this volume) Kent (this volume) assumes that sedi ments as old as Jurassic probably exist at this site, which would emphasize the antiquity of the present positions of Madagascar and Africa.

Volcanic components occur in the Cretaceous sedimentary rocks and are described by Vallier (this volume).

Figure 4. Site summary diagram for Site 241. 
SITE 242 (DAVIE RIDGE)

LEGEND (See Figure 2)

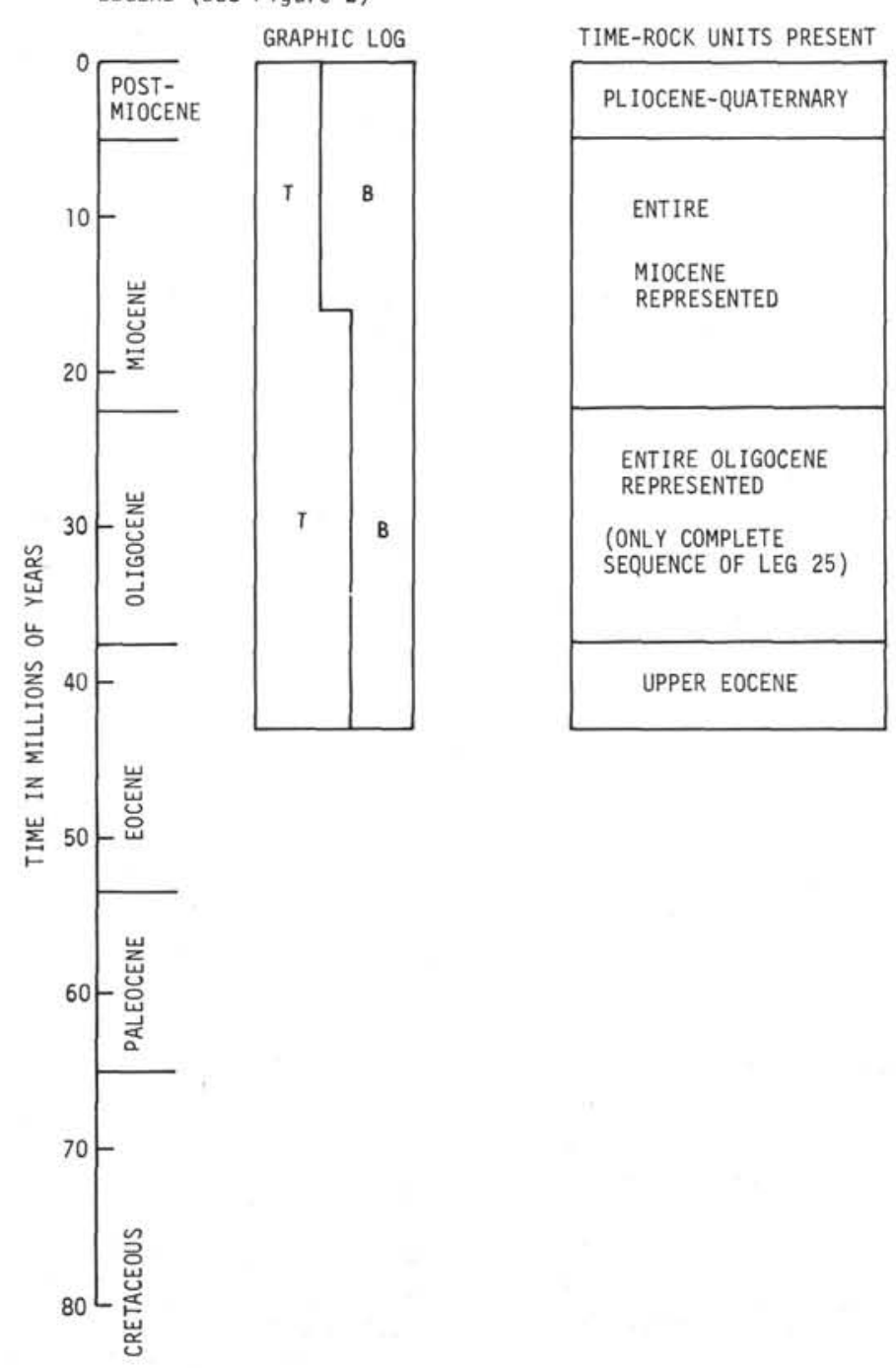

LITHOLOGIES

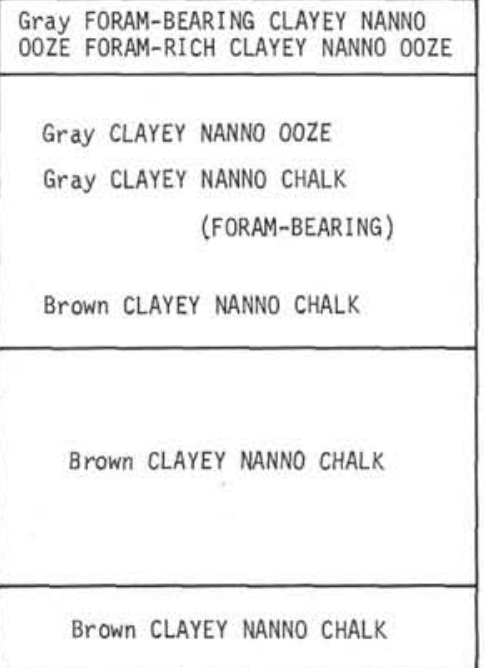

BrOWN CLAYEY NANNO CHALK
Site 242

Nearly uniform, uninterrupted deposition since late Eocene (note complete 01 igocene section) may last 40 m.y. Hemipelagic sediments with at least 50 percent calcareous components suggest that this site was at oceanic depth by the late Eocene, but above CCD.

A slight but distinct increase in biogenous components during mid-Miocene reflects increased productivity of overlying waters due to the initiation of the equatorial current system which in turn is related to northward drift of India (see Leclaire.

Sediment color change from brown (Fe-oxides) to gray (pyrite-bearing) in the mid-Miocene section sediment-water interface during middle Miocene (Leclaire, this volume).

A notable increase in both the terrigenous and biogenous sedimentation rates occurs from late Eocen to late Miocene (see site report chapter, Site 242) Tectonic instability of coastal Tanzania and of Davie Ridge provides one possible explanation.

Additional discussion is provided by Leclaire in this chapter.

Figure 5. Site summary diagram for Site 242. 
SITE 245 (MADAGASCAR BASIN)

LEGEND (See Fiqure 2)

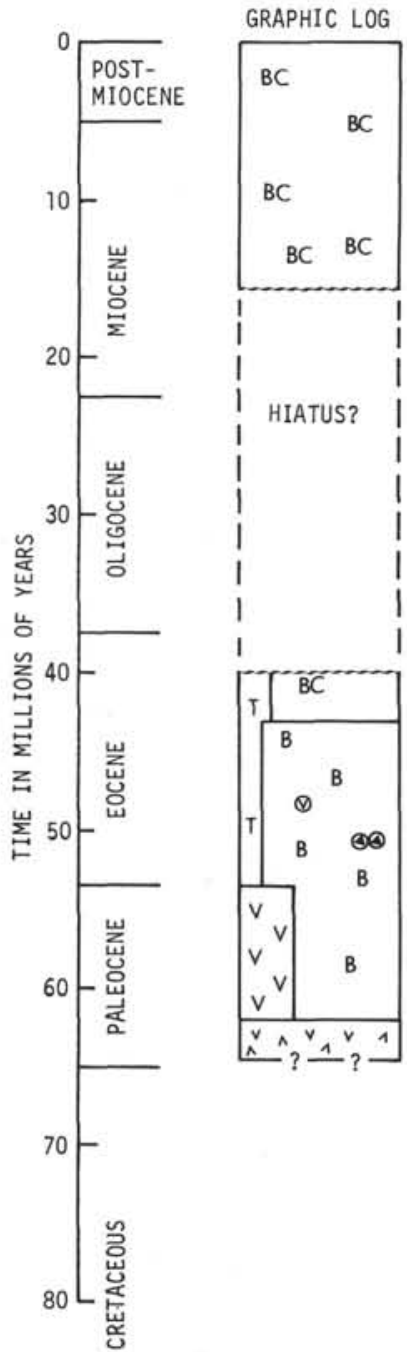

TIME-ROCK UNITS PRESENT

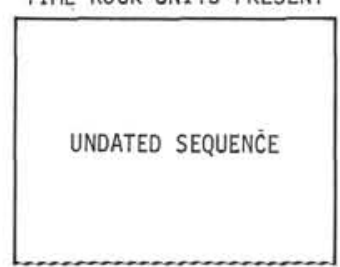

LITHOLOGIES

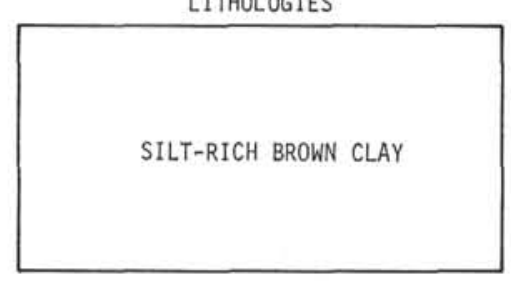

BOUNDARY IS

INFERRED ONLY

LOWER, MIDDLE, AND

UPPER EOCENE PRESENT

LOWER AND UPPER

PALEOCENE PRESENT

? - ?
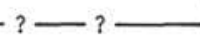

BROWN CLAY, BROWN NANNO-BEARING CLAY, NANNO OOZE CLAY-BEARING/ RICH NANNO CHALK, SILICIFIED NANNO CHALK, CHERT

CLAY-RICH NANNO CHALK,

DEVITRIFIED VOLCANIC ASH,

GLASSY-DIABASIC BASALT
BLACK $\mathrm{Fe} / \mathrm{Mn}$ CLAYEY NANNO CHALK

\section{Site 245}

Comments

Brown clays of Miocene and younger age reflect pelagic deposition below the CCD. O1der, PaleoceneEocene, deposits are chiefly pelagic calcareous biogenous material deposited above the CCD. Volcanogenic sediment, including 22 devitrified ash beds, occur in the Paleocene section, and at least minor volcanic components occur in the basalt sediments and may indicate an active, very rapid spreading center in close proximity to this site (Leclaire; Valtier: Warner and Gieskes; this volume).

Silicified (cristobalite-tridymite) chalks and cherts (chalcedonic) occur in Eocene biogenous sediments. Origin of silica is probably related to devitvolcanic emissions from the Central Indian Ocean from Ridge (Leclaire; Vallier; this volume).

The hiatus depicted may in fact not exist in whole or in part because it is based upon the absence of dateable fossils. This absence is due to dissolution of calcareous tests, the evidence for which is observed in the partially dissolved tests in the upper Eocene brown clays.

The diabase sill at the bottom of hole was dated $(K / A r)$ at $27 \pm 3$ m.y. (McKee, this volume). The sil has a tholeitic composition (Erlank and Reid, this volume).

Figure 6. Site summary diagram for Holes 245 and $245 \mathrm{~A}$. 
SITE 246 (MADAGASCAR RIDGE)

LEGEND (See Figure 2)

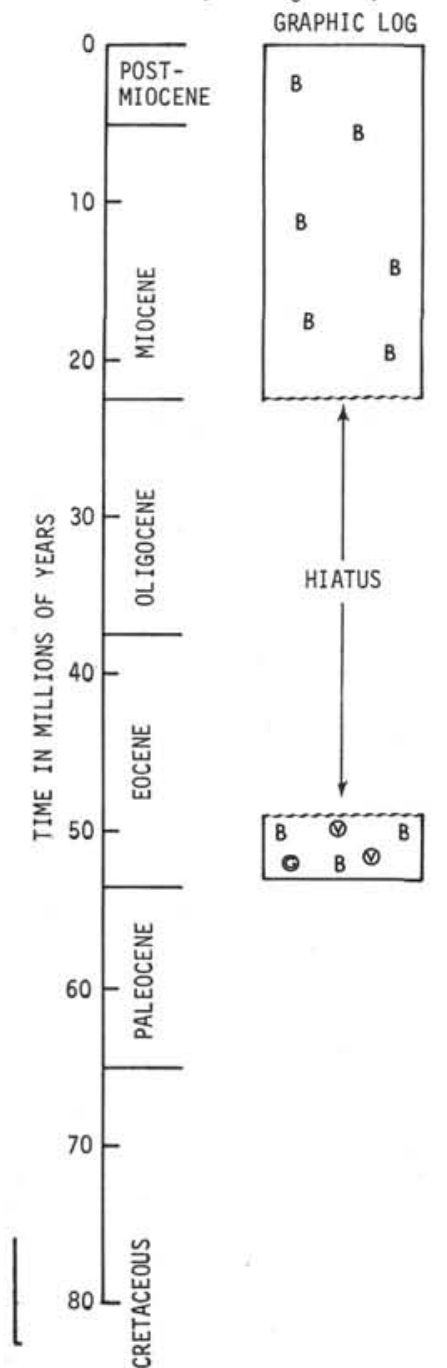

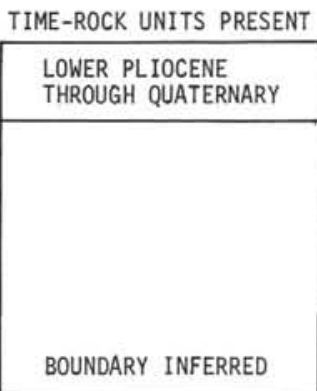

LOWER EOCENE: LOWEST COR

MAY BE PARTLY PALEOCENE
LITHOLOGIES

\begin{tabular}{|c|}
\hline $\begin{array}{l}\text { DETRITAL QUARTZ-RICH FORAM OOZE } \\
\text { FORAM NANNO OOZE }\end{array}$ \\
\hline NANNO-BEARING FORAM OOZE \\
\hline FORAM SAND AND CALCARENITE \\
\hline
\end{tabular}

FELDSPATHIC SHELLYY CARBONATE SAND. SAND. SHELLY CARBONATE SAND, VOL. SAND/BRECCIA.
Site 246

The section down to mid-Miocene is pelagic biogenous sediment representative of intermediate water chanically transported (reworked) biogenous deposit rich in shallow-water fossils, volcanic materials, and both detrital and authigenic glauconite are indicative of shallow-water environment during the Eocene, followed by deepening.

Volcanics occur in the Eocene as sand, breccia, and tuff. The latter are interpreted as having forme in shallow water (Valtier, this volume) and were probably derived locally from the Madagascar Ridge. Minerals in the terrigenous fraction indicate both crystalline and volcanic provenance materials. The hiatus may be explained by erosion of the ridge, which remained at or near wave-base during Eocene and date the subsidence of the Madagascar Ridge.

\section{Figure 7. Site summary diagram for Site 246.}




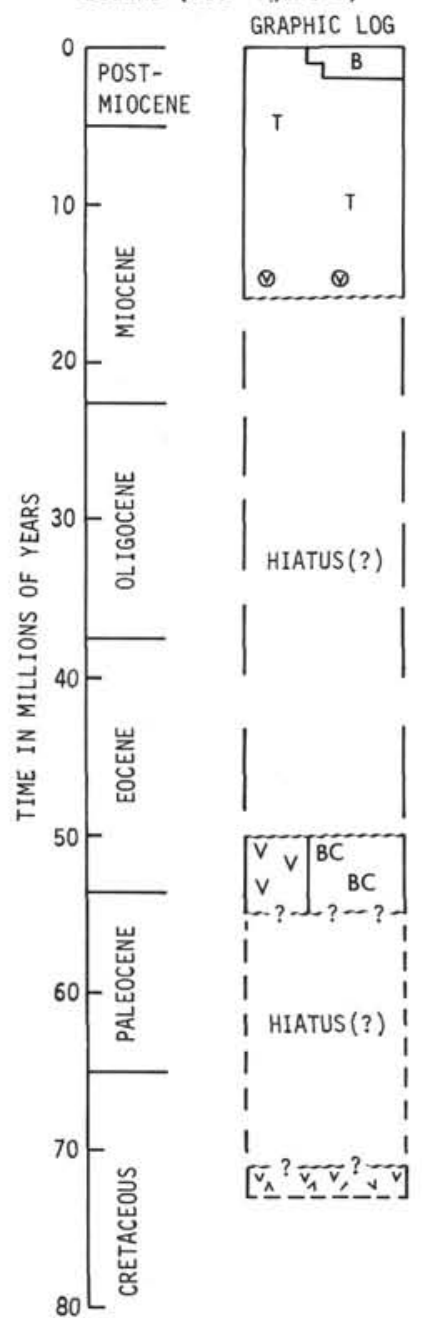

TIME-ROCK UNITS PRESENT PLEISTOCENE

MIDDLE AND UPPER

MIOCENE RECOGNIZED;

ENTIRE MIOCENE

MAY BE PRESENT

\section{ONLY LOWER EOCENE} RECOGNIZED

K-Ar DATE $72 \pm 7$ m.y.
LITHOLOGIES Greenish gray CLAYEY SANDY SILT, TAVMO graY SILT/CLAY-RICH

\section{Dark greenish gray SILTY SAND,} COARSE QUARTZ SAND

reenish gray SILT BEARING, SILTCLAY, Brown CLAY, brown SILT-BEARI CLAY.

Dark gray PORPHYRITIC BASALT
Site 248

The entire section to upper $\mathrm{Pliocene}$ is nonbiogenic. The Paleocene-Eocene brown clay probably represents dissolution of biogenic components. A high amount of volcanogenic components suggest extensive volcanism in Eocene time (Vallier, this volume).

The Miocene-Pliocene section has been predominately deposited as turbidites. The rich PliocenePleistocene biogenic deposits are correlative with similar deposits found at sites 240, 241, and 242. These may represent increased biogenic productivity concurrent with a decrease in terrigenous supply.

Miocene massive sand deposits apparently record the uplift of adjacent continental areas and probab this volume). Heavy minerals suggest silicic plutonic, pegmatite, and volcanic source areas of east Africa or the Madagascar Ridge.

Two hiatuses are suspected in the section; however, both may be more apparent than real:

1) A Late Cretaceous-late Paleocene hiatus - the basalt has an absolute age date of $72 \pm 7 \mathrm{~m} \cdot \mathrm{y}$. (Mckee, this volume). The oldest sediment recovered, but not resting directly on the basalt, is upper Paleocene. The interval directly above basalt was cored but not completely recovered.

2) An Early Eocene-Miocene hiatus-sediment recovery was good but lacked dateable fossils, thereby preventing a definite demonstration of a hiatus. How ever, a calculated low sedimentation rate $(=3.5 \mathrm{~m} /$ infer that a hictus does exist (Leclaire, this vol ume).

The contrast between the silty clay and the Miocene massive sand is explained by Kent (this volume), who attributes the accumulation of

The basalt at this site was dated by McKee (this volume) and well described by Erlank and Reid (this

Figure 8. Site summary diagram for Site 248. 
SITE 249 (MOZAMBIQUE RIDGE)

LEGEND (See Figure 2)

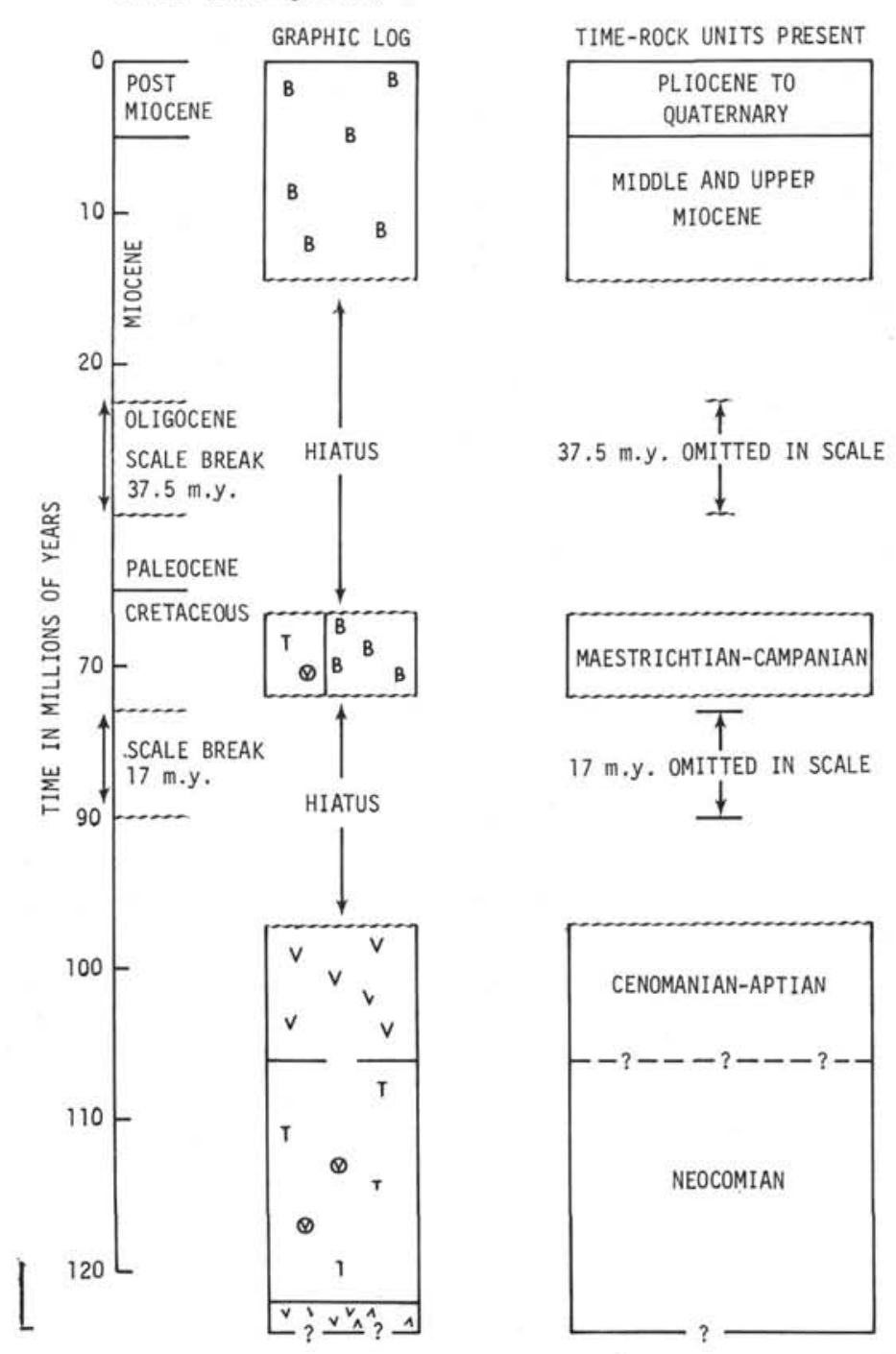

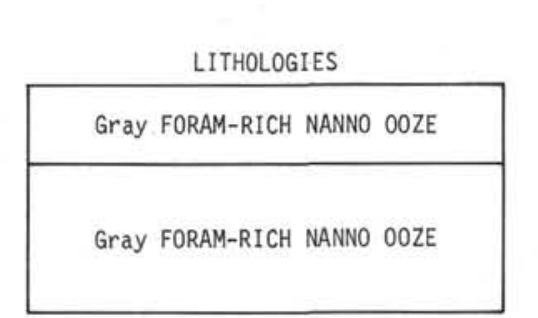

Brown and gray FORAM-BEARING CLAY-RICH NANNO CHALK

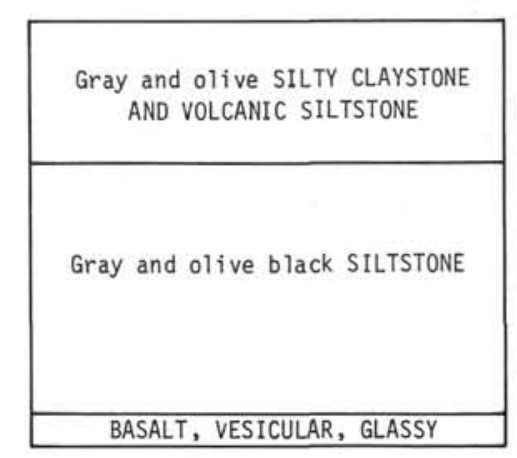

Site 249

Comments

A striking contrast exists between the terrigenous/volcanogenic sediments of the Cretaceous and the biogenic deposits of the Min the cretatenary. gests localized basin development. The sediments were deposited in a reducing environment as evidenced by pyrite and a high organic carbon content. The combination of a ridge basin, and this particular type of sediment is a unique feature for the Indian Ocean. Further discussion on this problem is found elsewhere in this chapter.

Pyroclastic and epiclastic volcanogenic sediments occur above the terrigenous sequence and are erosion of nearby volcanic landmasses (Vallier, this volume)

The change to biogenic sediments in the Upper Cretaceous possibly marks the uplift of the Mozambique genic sediments in the Miocene to Quaternary attest to the stability of the ridge at that time.

The two hiatuses shown have well-defined limits as evidenced by paleontological and lithological changes. The lower hiatus is possibly correlative with the uplift of the Mozambique Ridge and the mainland regression discussed by Kent (this volume).

The upper hiatus encompasses nearly $50 \mathrm{~m} . \mathrm{y}$. which is the longest noted in Leg 25. It is suggested that this hiatus is, for the most part, due to the

Figure 9. Site summary diagram for Site 249. 


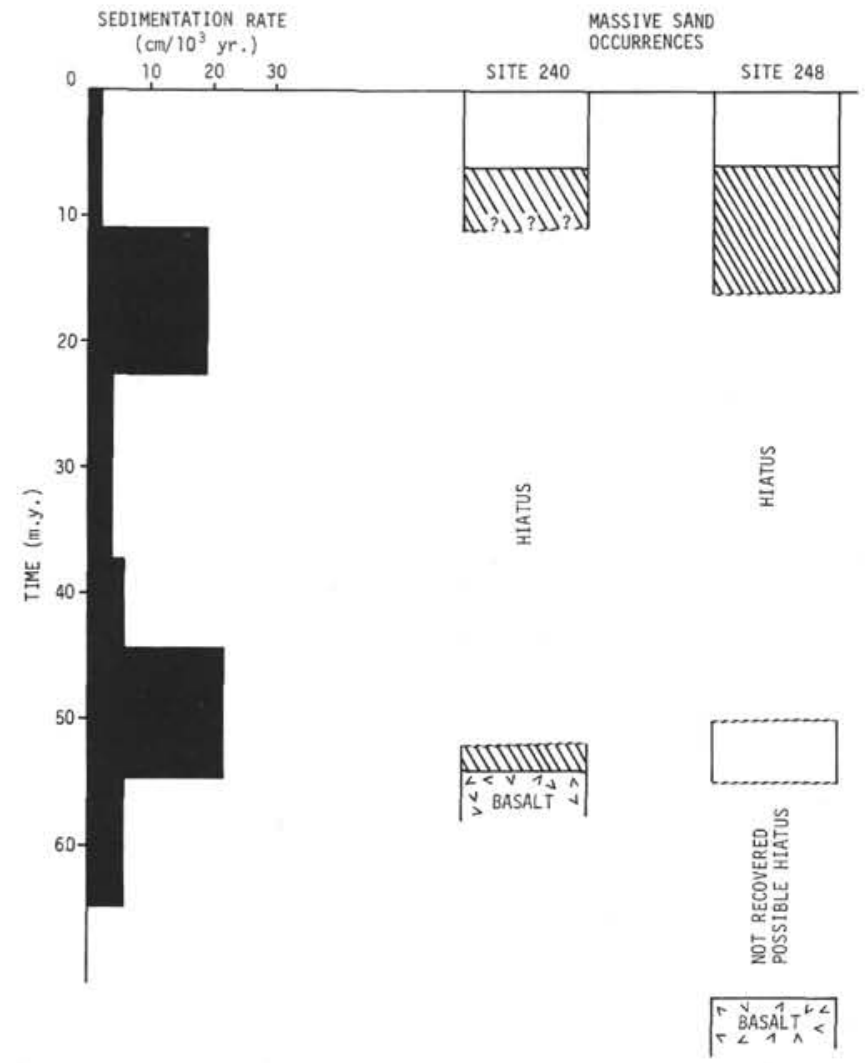

Figure 10. Correlation of massive sand occurrences (diagonal lines) with sedimentation rate on the continental shelf of East Africa (after Kent et al., 1971). Note that hiatuses seem to correlate with periods of low sedimentation rates before 10 m.y. ago.

correlative sedimentary sequences in Africa and Madagascar to rifting that took place between those two landmasses. Sigal (this volume) correlates the Cretaceous sediments at Site 249 with those in Africa and Madagascar on a broad regional scale. This discussion offers some points of agreement with these authors, particularly with regard to the development of the Cretaceous marine sequences and to the rifting which allowed both the creation of a deep basin in the Early Cretaceous and, subsequently, the existence of open marine conditions in the area by the Late Cretaceous.

Age of the eruptive rock at the base of the sediment column in Site 249 is not known (see discussion by Sigal, this volume). It is Neocomian or older, but a true age cannot be established because of the absence of diagnostic fossils and the lack of radiometric dates. One major characteristic of the basalt is noteworthy. Vesicles are large, some more than $2 \mathrm{~cm}$ in diameter. Recognizing that size of vesicles is not a particularly good criterion for establishing the place of extrusion (subaerial, shallow water, or deep water), it does suggest that the eruptions occurred either on land or in shallow water.

The sediments of Early Cretaceous age at Site 249 include two minor facies in Unit III (see Chapter 10, this volume). Although they are poorly dated because of the lack of diagnostic fossil species, the paleontologic ages are sufficient to give a relatively good time framework. The older facies, subunit IIIB, is mostly black and dark brown silty claystone with minor amounts of silty limestone and siltstone. The age of this subunit is Neocomian (oldest probably is about Valanginian-Hauterivian). The younger facies (subunit IIIA) is strongly volcanogenic, but it includes some beds of silty claystone and silty limestone. The age of subunit IIIA falls in about the middle of the Cretaceous (Aptian-Cenomanian). Unit III is 121 meters thick and is predominantly black and dark brown in color, the result of high carbon and pyrite contents. This unit apparently was deposited in a poorly oxygenated, euxinic environment.

Flores (1973) distinguishes a middle Cretaceous marine sequence, the Domo Formation of Aptian-Cenomanian age, in deep wells of both the Save River and eastern Sul Do Save areas of Mozambique, which is partly correlative with the black and dark brown Cretaceous sediments of Site 249 (Figure 11). He invokes a south to north transgression, which would easily account for the existence of older sediments both in the southern part of Mozambique and at Site 249. The sediments are similar; the Domo Formation consists of dark gray to black, thin-bedded marly shales with sand streaks, and ranges in age from Aptian-Albian (south) to Albian-Cenomanian and even Turonian (north). The depositional environment was euxinic. The formation becomes progressively younger to the north, reaching well up into the Turonian near the mouth of Save River. Flores also discusses changes in thickness of the Domo Formation, which has a minimum thickness in the southernmost well (between the mouth of the Limpopo River and Imhambane) of about 325 meters and a maximum of about 1525 meters farther north at Imhambane. Characteristics of the Domo Formation, both age and lithologies, are similar to those of Unit III at Site 249. They are partly correlative (part of the sediments at Site 249 is older) which strengthens the contention of Flores $(1973$, p. 93) that there was a south to north transgression in a graben-like structure where euxinic conditions prevailed. The depositional center of the basin apparently was near the Mozambique coast at Imhambane, where the thickness is about 1525 meters.

The overlying unit at Site 249 (Unit II) of late Senonian (Campanian and Maestrichtian) age, is apparently an offshore facies of the Grudja Formation (Figure 11). A change from euxinic to open marine conditions occurred in both the Mozambique and the Site 249 areas at this time. There is a hiatus at Site 249 that is not recorded in the Cretaceous of Mozambique.

The basin in which the black and dark brown Cretaceous sediments were deposited, apparently was more extensive than previously thought. Also, the conclusions of Flores (1973) are strengthened by our findings with regard to a south to north transgression in the late Early Cretaceous and to a change from restricted to open marine conditions in the Late Cretaceous. If we assume that the basalt at Site 249 is equivalent to the Movene Basalt in Mozambique, then a simple geologic history can be outlined. In the Early Cretaceous (Neocomian), the area between Africa and Madagascar subsided in a graben-like structure as a result of rifting and was subsequently invaded by the sea. The area continued subsiding from south to north, thereby allowing a marine transgression. In the Late Cretaceous, continued 

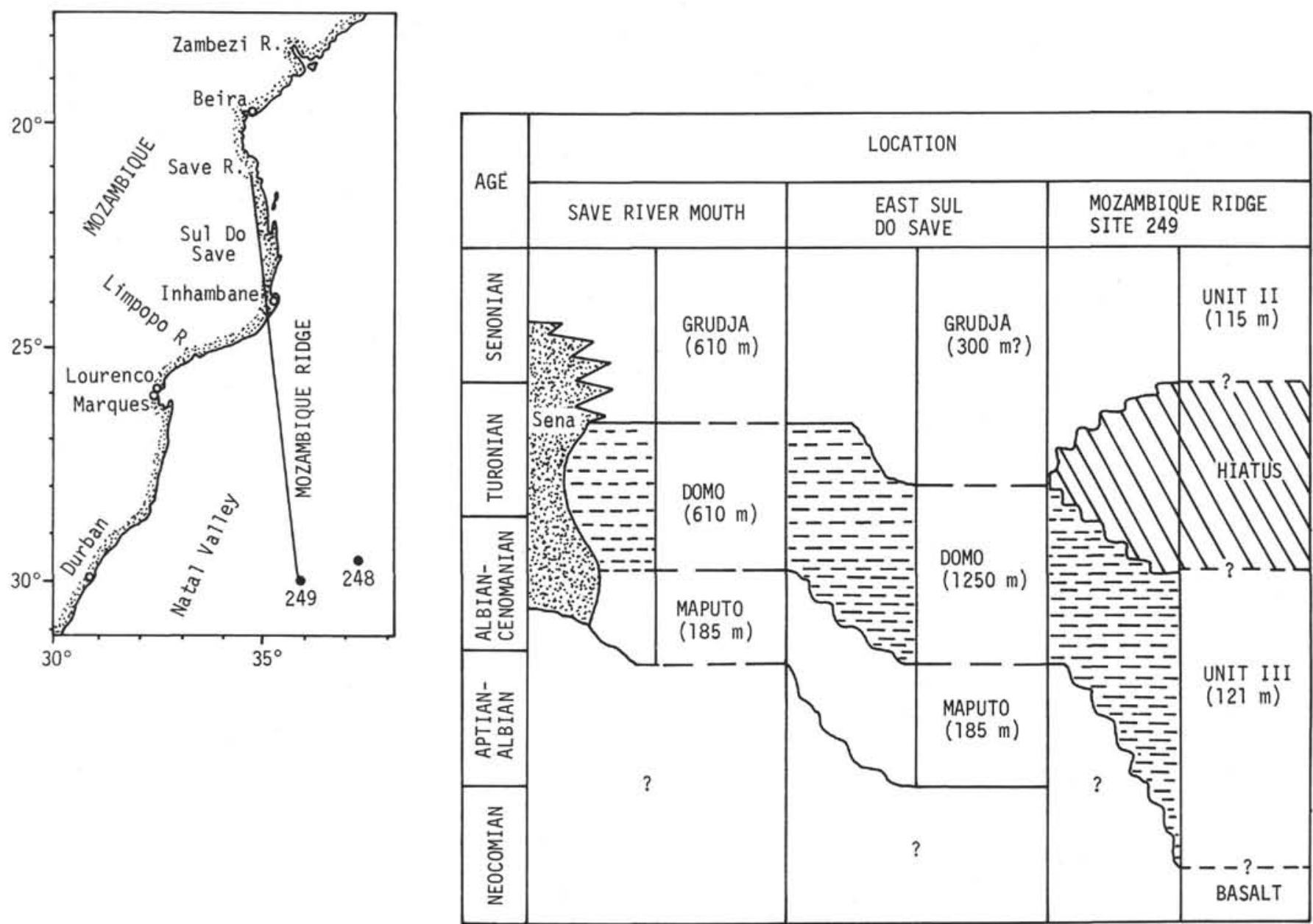

Figure 11. Correlation chart for Cretaceous rocks between Save River and Site 249. Index map shows approximate line of section northwest to southeast. Data in Mozambique from Flores (1973).

rifting opened the seaway which changed conditions from euxinic to open marine.

The Mozambique Ridge was created at least by the Late Cretaceous, perhaps synchronous with the formation of the Mozambique Basin. The hiatus in the Late Cretaceous of Site 249 may be the result of strong current action along the ridge.

\section{Upper Cretaceous Flysch and the Rifting of East Africa}

The Upper Cretaceous rocks at Site 241 were deposited below the carbonate compensation depth (CCD); therefore, it is likely that oceanic conditions existed along East Africa at this time. These deep-sea deposits also preclude the location of Madagascar being closely adjacent to Tanzania and Kenya during much of the Cretaceous.

Flexotir profiles indicate at least $3.15 \mathrm{~km}$ of sedimentary rocks between the deepest penetration at Site 241 and the acoustic basement. We have estimated the age of the oldest deposits overlying this basement at 147 m.y. by downward projection of sedimentation rates determined in the Upper Cretaceous flysch. Thus, it is likely that sedimentation began at Site 241 no later than upper Jurassic. Moreover, if the acoustic basement represents Karroo equivalents, the accumulation of sediments at Site 241 could have begun much earlier. The sedimentary deposits cored at Site 241 are consistent with the rifting of the East African continental margin at least by Early Cretaceous.

\section{Mineralogic Considerations}

Details of the mineralogy of terrigenous sediments and of the glauconite mineralogy at Site 246 have been discussed by Girdley and White (this volume) and White (this volume). Therefore, only their conclusions as they are related to other facets of the total lithologic picture are discussed here.

\section{Heavy and Light Mineralogy}

The heavy and light terrigenous mineral suites seem more distinctive because of similarities than because of any notable differences. Such similarities exist with depth at a single site, between certain site grouping (i.e., Site 239, 240 , and 241 and Site 246 and 248), among the five sites examined, and between the regional geology (and thus provenance areas) of East Africa and Madagascar.

While there are some differences in the absolute abundances of the minerals as a function of depth in a core, the relative abundance and the characteristic minerals represented are fairly constant throughout the interval 
examined and thus seemingly indicate unchanging provenances with passage of time. Comparisons of the mineralogy between site groupings, or among all sites, reinforces the interpretations that East Africa and Madagascar were close to the sites throughout most of the Late Cretaceous and the Cenozoic. The mineralogical similarities at the sites also are supportive of the minerals which originated from the same provenace areas.

Although similarities in the regional geology of Africa and Madagascar prevent a clear-cut distinction between these source areas on a mineralogical basis, close correlation between mineralogy of continental bedrock and terrigenous sediments encountered on Leg 25 demonstrates that either or both acted as provenances for such sediment. The heavy and light mineral suites are very indicative of complex provenances that include acidic plutonic, pegmatitic, metamorphic, and volcanic pyroclastic or epiclastic contributions.

\section{Glauconite Mineralogy}

Glauconite in the sediments of Site 246 does not reveal any new or startling evidence bearing on the precise origin of the mineral. Evidence is conclusive that the glauconite is both authigenic (predominately associated with clay infillings in biogenous shells and tests) and detrital (reworked pellets with an initial clay-biogenous origin). However, the glauconite occurrence does show a very positive indication of epeirogenic movements on the
Madagascar Ridge. The lower Eocene deposits, in which the glauconite is found, has an associated distinctive biogenic assemblage. This assemblage contains shallow-water benthonic foraminifera, littoral benthonics of other faunas, and what can be characterized as bioclastic, shallow-water debris. Thus, the paleontological assemblage and the sedimentological and chemical environment requirements for glauconite seemingly dictate that the Madagascar Ridge had a maximum depth of 250 to 700 meters during early Eocene time (White, this volume). This is in direct contrast to the middle Miocene to Quaternary sediments which most certainly indicate water depths of at least 1000 meters (see Chapter 8, this volume). This sediment sequence is preceded by an early middle Eocene to early Miocene hiatus of approximately 27 m.y. duration.

The glauconite, shallow paleontologic fauna and possibly the volcanic products in the early Eocene, illustrate a shallow environment for the Madagascar Ridge. Both light and heavy minerals (i.e., tourmaline) point to detrital contributions, possibly from Madagascar. The absence of glauconite and the paleontological data for the middle Miocene attest to subsidence of the ridge. The present depth at the site is 1030 meters.

\section{Sedimentation Rates}

The sedimentation rate diagram for Leg 25 (Figure 12) is combined from the individual sedimentation rate diagrams for each site. Its purpose is to illustrate the results of the

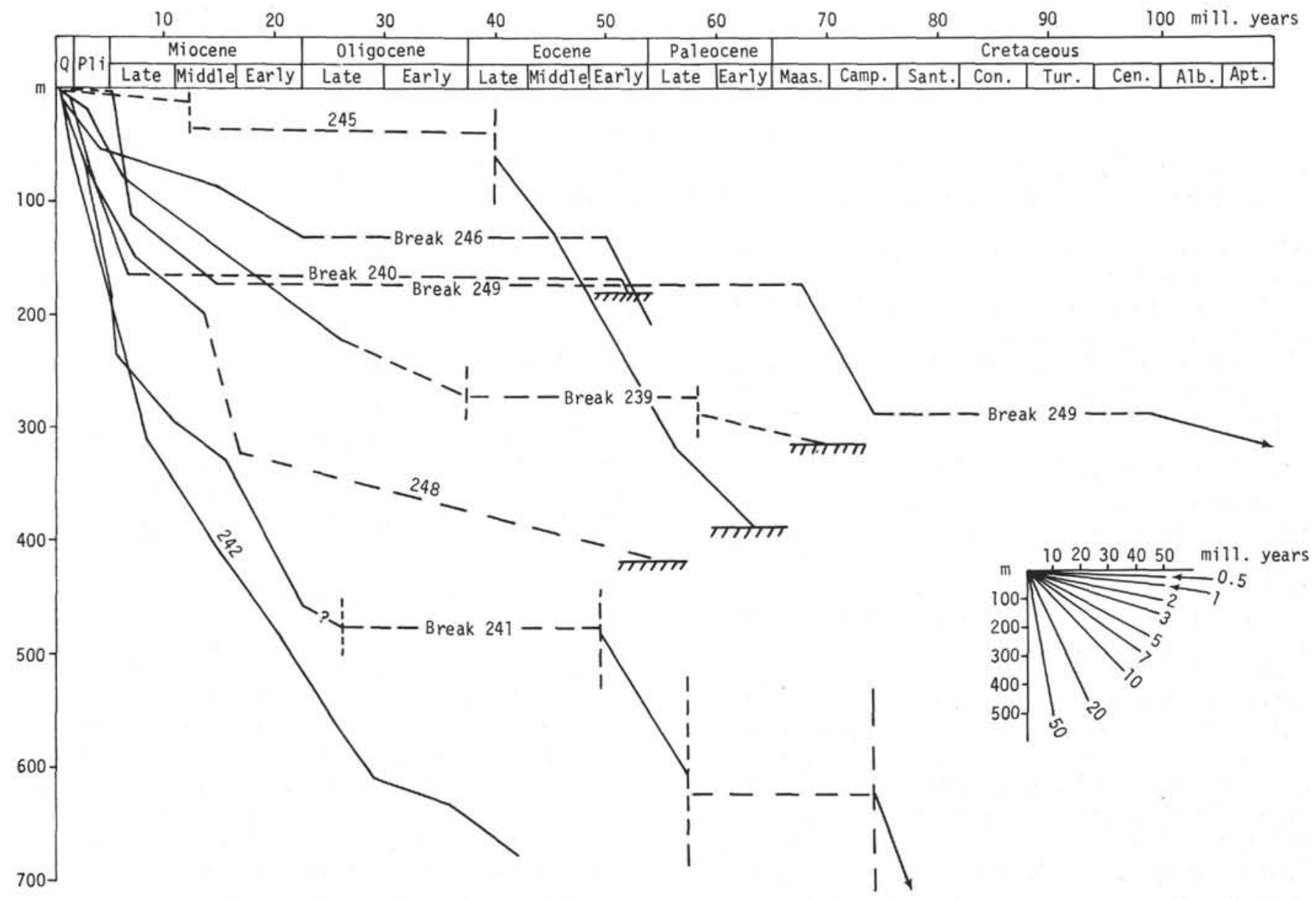

Figure 12. Sedimentation rates for the sites of Leg 25 . 
biostratigraphic investigation and to aid in a better understanding of the sedimentological results.

The greater a given line deviates from the horizontal position the higher the rate of sedimentation. Broken lines indicate uncored or biostratigraphically unidentified sections. Where no calcareous fossils for dating occur, it is, of course, a point of discussion as to whether these comprise a hiatus or represent a very low sedimentation rate in sediment. Horizontal lines indicate a gap in the sediments (suggesting nondeposition or erosion). Comments on the mode of construction of the sedimentation rate curves are given in Chapter 1, and the individual sedimentation rate curves are discussed in the appropriate site reports (this volume).

For the purposes of this lithologic summary, some general conclusions can be drawn from the sedimentation rate diagrams. At least within the Miocene, cores from the continental margin (Sites 241, 242, and 249) can be distinguished from those of the deep-sea basins (Sites 239 and 248) by the different gradient of the sedimentation rate curves (high rate near the continental margin). Sedimentation rates equally as high as those at the continental margin sites can be observed for the early Eocene, Paleocene, and uppermost Late Cretaceous in Sites $241,245,246$, and 249 . There, the sediment supply must have been even higher because the Paleogene and Late Cretaceous sediments are partly depleted of calcium carbonate by dissolution of biogenous components and their degree of compaction is higher.

\section{Hiatuses, Compaction, and Condensed Sequences}

Hiatuses have been detected in seven of the eleven sites drilled (Figure 13). Two chapters in this volume (Leclaire and Kent) deal with this problem. However, further discussion seems to be of some usefulness here in order to define accurately the limit of the hiatuses and at the same time to consider lithologic facies.

\section{Basin Hiatuses}

In Somali Basin, at Site 240, the break in the sedimentary column is well delineated (Figure 13). In fact, a biogenic sediment about $53 \mathrm{~m}$.y. old is directly overlain by a terrigenous sequence which is $10 \mathrm{~m}$.y. old at the base. At Site 241 (Figure 13), along the extreme western side of Somali Basin, the boundary between a 70-76 m.y. old brown claystone and an approximately 57 m.y. old claystone was not observed, but it is inferred to be in an uncored interval. The 57 m.y. age is not certain, and the sediment could be older. Therefore, the uncored interval of 40 meters encompasses 16 m.y. Surprisingly, if the sedimentation were continuous, a simple calculation gives $2.5 \mathrm{~m} / \mathrm{m} . \mathrm{y}$. as a rate of sedimentation. Taking into account that the core above the presumed hiatus consists of brown claystone deposited below the CCD, $2.5 \mathrm{~m} / \mathrm{m}$.y. is probably the true rate of sedimentation. Additionally, the brown claystone consists of compacted brown clay. Consequently, the presence of a real hiatus is not warranted here, but rather, one may suspect a compacted (condensed) lithologic sequence. Higher in the column at Site 241, another

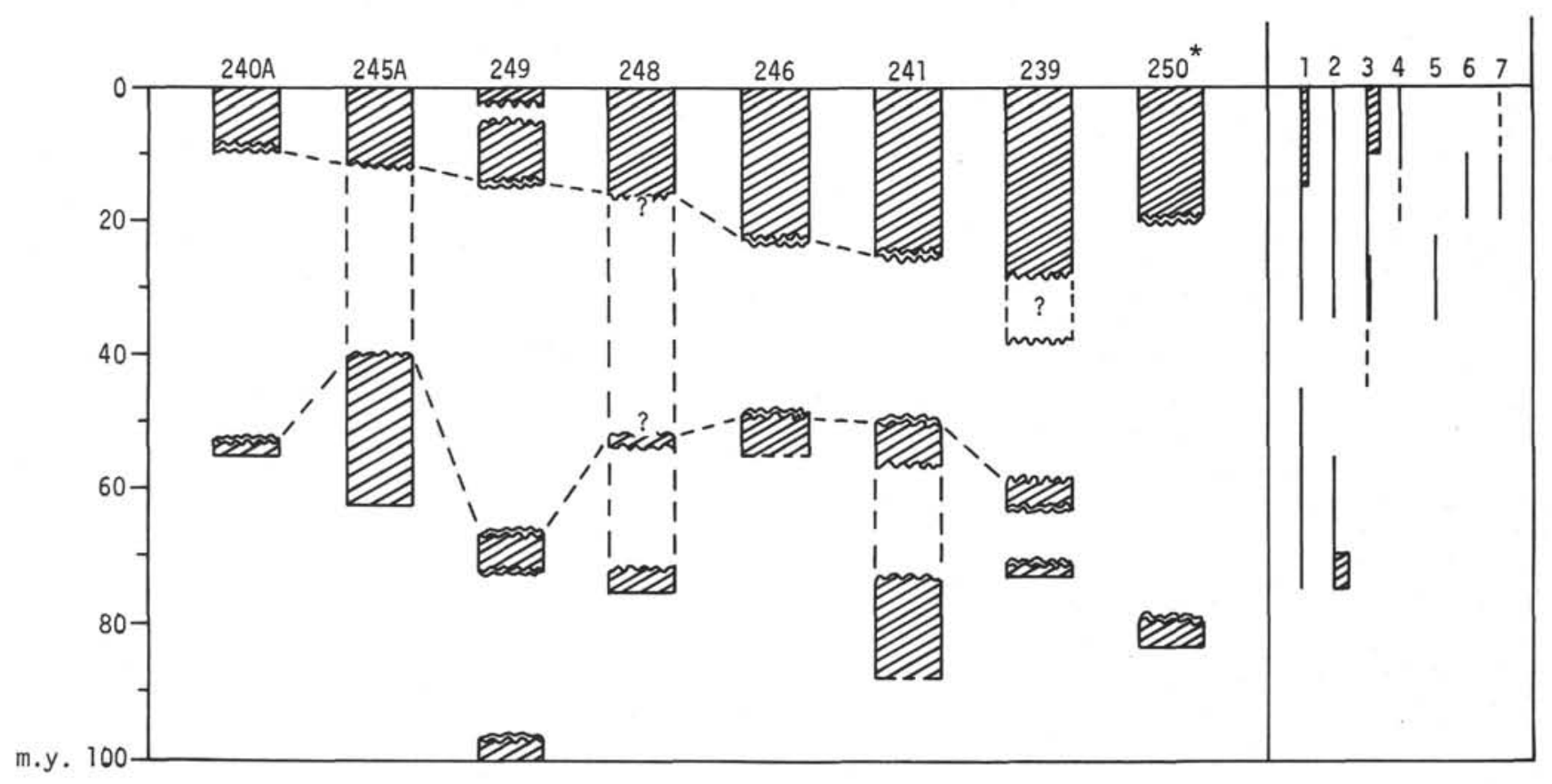

1. Epochs of notable spreading in the Central Indian Ocean.

2. Spreading of Indian Ocean.

3. Spreading between Antarctica and Australia.

4. Downwarping of Madagascar Plateau.

5. 0ligocene regression on East African coast.

6. Miocene transgression on East African coast.

7. Uplift of the South Western Branch.

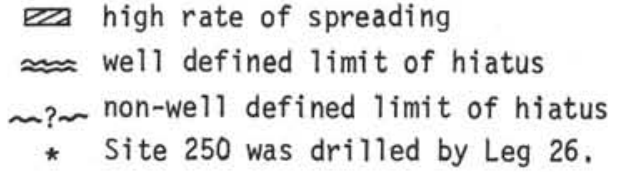

23 high rate of spreading

$\sim$ ? non-well defined limit of hiatus

* Site 250 was drilled by Leg 26.

Figure 13. The central western Indian Ocean hiatuses and some of the major events of the Indian Ocean history (from Sigal, modified by Leclaire). 
anomalous feature occurs in a terrigenous sequence. An interruption of the sedimentation between about $50 \mathrm{~m} . \mathrm{y}$. and 25 m.y. is interpreted. Assuming an unbroken sequence, the sedimentation rate would be $0.8 \mathrm{~m} / \mathrm{m} . y$., a rate which is far too low for a detrital sequence. Despite the fact that the break has not been actually observed in a core, it can reasonably be inferred that while a hiatus may exist in an uncored interval, it may be somewhat more restricted than previously supposed.

In the Mascarene Basin (Site 239), a relatively well-defined hiatus occurs in the brown clay sequence near the bottom of the hole (Figure 13). It encompasses the interval from 71-72 m.y. to 61-64 m.y. The whole sedimentary sequence, above and below this break, was cored, which thereby definitely demonstrates the presence of a hiatus. Still higher in the column at Site 239, in the overlying brown clay and brown silty clay, another break is postulated. It would extend from about 59 m.y. up to about 38 m.y. However, fossils are very rare and are not well preserved in the brown clay sequence and, consequently, the late Paleocene age is somewhat uncertain. The late late Eocene age is obtained from a thin $(10 \mathrm{~cm})$ bed of pure calcareous deposits, rich in nannofossils and micarb. The foraminifera do not yield a precise age. This bed, containing fairly well-preserved nannofossils, is in a barren brown clay sequence that was deposited below the CCD. One can reasonably suspect an allochtonous origin and thus consider this deposit to be a pelagic turbidite. In this case, the hiatus would be longer and its position undetermined. However, the inference that a hiatus is present seems reasonable.

In the Madagascar Basin (Site 245) (Figure 13), a hiatus of about 30 m.y. duration is inferred from paleontological data. It would range from 40 m.y. to about 12 m.y; unfortunately, it was not observed in a core. In fact, its presence is inferred and the hiatus is placed in an uncored interval. In addition, the middle Miocene age obtained from nannofossils is uncertain and came from a thin calcareous bed intercalated in a barren brown clay. The calcareous bed may be displaced. Assuming continuous sedimentation from 40 m.y. until the present, the sedimentation rate would have been about $1.5 \mathrm{~m} / \mathrm{m}$.y. A low sedimentation rate such as this is not surprising for brown clay and has been previously mentioned elsewhere (Leclaire, this volume). Thus, it may be possible that the hiatus does not exist.

At Site 248 in the Mozambique Basin, a lack of information due to the absence of calcareous fossils and the unreliable age given by radiolarians does not allow proof for the presence of a hiatus between the early Eocene and the Miocene (Figure 13). However, assuming uninterrupted sedimentation, the estimated sedimentation rate of 2.5 $\mathrm{m} / \mathrm{m} . \mathrm{y}$. is far too low taking into account the massive detrital supplies exhibited by the lithologic sequence. Another possibility is to assume the presence of a "condensed sequence" which compacted as biogenous components dissolved.

An absolute age of $72 \pm 7$ m.y. (K/Ar) has been obtained for the basaltic "basement" (McKee, this volume). Because the basement is overlain by lower Eocene biogenic sediments, an additional break at the bottom of Hole 248 might be inferred.

\section{Ridge Hiatuses}

Breaks in the sedimentary columns of Madagascar (Site 246) and Mozambique (Site 249) ridges are fairly well delineated (Figure 13), especially at Site 249 where the contact between the Upper Cretaceous and middle Miocene sediments is well marked in Core 16 by a sharp lithologic change. Here, both the lithologic and paleontologic data indicate the presence of a hiatus.

The basin hiatuses seem to be far less defined than those on the ridges. The lack of cores, or poor core recovery, and the absence of fossils may sometimes lead to inferences concerning the presence of hiatuses which are not real but rather are "information gaps". Possibly, in some cases, current scouring and compaction are the cause of what appear to be very low sedimentation rates. Slow rates of sedimentation calculated from cored intervals have been noticed in some sites $(239,246$, and 249) and may have the same causes. In any case, the assessment of the presence of hiatuses, especially in brown clay or in brown claystone deposited below the $\mathrm{CCD}$, have to be made with caution.

\section{Remarks on the Causes of Hiatuses}

Leclaire (this volume) has based his interpretation of hiatuses on submarine erosion by current scouring and by dissolution of calcareous components of the sediments at the CCD. This would account for the end of a hiatus, e.g., the one that occurs in several holes by late Oligocene-early Miocene times (Figure 13). Sedimentation would have started again when "deep boundary undercurrents" were sufficiently weakened or deflected by uplift of the Southwest Indian Ridge. This interpretation is not in conflict with others, such as Kent (this volume) who postulated correlation between hiatuses and tectonic events affecting east and southeast Africa during Cretaceous and Cenozoic. In effect, in the case of a peneplanation and regression, the supply of terrigenous material will be lowered, favoring indirectly the effectiveness of the erosion by bottom currents. However, such correlation, loosely defined, cannot account for hiatuses in pure pelagic sequences. Additionally, current scouring is a physical process, the action of which is presently well documented. From the foregoing, it appears to us that attempts to show that these hiatuses are regional or worldwide by speculation on a worldwide basis (Rona, 1973) are still premature.

\section{REFERENCES}

Berggren, W. H., 1972. A Cenozoic time scale-some implications for regional geology and paleobiogeography: Lethaia, v. 5, p. 195-215.

Blant, G., 1973. Structure et Paléogéographie du littoral méridional et oriental de L'Afrique. In Blant, G. (Ed.), Sedimentary basins of the African coasts, part II, south and east coasts: Paris (Assoc. African Geol. Surv.), p. 195-231.

Casey, R., 1964. The Cretaceous period. In Harland, W. B., Smith, A. G., and Wilcock, B., The Phanerozoic time scale: Geol. Soc. London Quat. J., Suppl. 1, p. 193-202.

Flores, G., 1970. Suggested origin of the Mozambique Channel: Geol. Soc. S. Africa Trans., v. 73, p. 1-16.

1973. The Cretaceous and Tertiary sedimentary basins of Mozambique and Zululand. In Blant, G. (Ed.), Sedimentary basins of the African coasts, part II, south 
and east coasts; Paris (Assoc. African Geol. Surv.), p. 81-112.

Kent, P. E., Hunt, J. A., Johnstone, D. W., 1971. The geology and geophysics of coastal Tanzania: Nat. Env. Res. Council, Inst. Geol. Sci. Geophys. paper no. 6.

Luyendyk, B. P., Davies, T. A., Rudolfo, K. A., Kempe, D. R. C., McKelvey, B. C., Leidy, R. D., Horvath, G. J.,
Hyndman, R. D., Theirstien, H. R., Boltovskoy, E., Doyle, P., 1973. Across the southern Indian Ocean aboard Glomar Challenger: Geotimes, March 1973, p. 16-19.

Rona, P. A., 1973. Worldwide unconformities in marine sediments related to eustatic changes of sea level: Nature Phys. Sci., v. 244, July 9, 1973, p. 25-26. 